\title{
THE INFLUENCE OF THE MURDER COMMANDMENT IN 1 CORINTHIANS
}

\author{
William Andrew Williamson and Brian S. Rosner \\ (andyrose2@gmail.com / b.rosner@ridley.edu.au)
}

\begin{abstract}
Summary
This article investigates the influence of the Decalogue commandment not to murder in 1 Corinthians as a case study of Paul's dependence on the law for ethics. Paul does not quote or allude to the murder commandment in the letter. However, there is good evidence that the murder commandment, in line with its interpretation in the Jewish Scriptures and early Jewish moral teaching, is a fundamental presupposition of Paul's moral teaching in 1 Corinthians. This can be seen in Paul's use of murder as a metaphor and of antisocial vices as synecdoches for the murder commandment, his concern about the moral impurity of such murder, and the close relationship between Paul's call to love and his call to forsake such antisocial vices. Reading 1 Corinthians with the murder commandment in mind, especially as it was understood in ancient Judaism, sheds light on the nature of the problems in the church of God in Corinth and clarifies Paul's response to the problems in the church.
\end{abstract}

\section{Introduction}

The relationship between the Apostle Paul and the law of Moses is a longstanding and ongoing area of research with many historical, exegetical, and theological dimensions. ${ }^{1}$ One question that remains a matter of dispute concerns the extent to which, given his negative critique

1 For a recent treatment see Brian S. Rosner, Paul and the Law: Keeping the Commandments of God (Downers Grove: IVP, 2013). 
of the law, ${ }^{2}$ Paul continues to use the law to regulate the conduct of believers in Christ. As James D. G. Dunn states: 'Any continuing role for the Torah (Jewish law) in Paul's ethics is a matter of continuing controversy.' ${ }^{3}$

As a case study of Paul's dependence on the Law for ethics this article considers the influence of the Decalogue commandment not to murder (Exod. 20:13; Deut. 5:17) in 1 Corinthians. ${ }^{4}$ Paul does not quote the murder commandment in 1 Corinthians, nor does the 'murder' lexeme ( letter. However, noting such explicit indications of influence is misleading. Evidence of more subtle and indirect influence needs to be considered. ${ }^{5}$ Critically, the way in which the murder commandment was understood in the Jewish Scriptures and early Jewish moral teaching provides the essential background for gauging its influence.

The influence of the murder commandment in 1 Corinthians can be seen in ways that correspond to four developments in the history of its interpretation in Paul's Jewish inheritance: (1) the use of murder as a metaphor for antisocial vices; (2) certain vices as synecdoches for murder; (3) murder as a major form of moral impurity; and (4) love as the opposite of and ultimate solution to murder. Reading 1 Corinthians with the murder commandment in mind, especially as it was understood in ancient Judaism, sheds light on the nature of the problems in the church of God in Corinth and clarifies Paul's response to the problems in the church.

2 E.g. according to Paul, the Law is an enslaving power, increases sin, and is used by sin to cause death (Gal. 4.1-10; Rom. 5.20; 7.5). In 1 Cor. 9:21 Paul asserts that he is not under the Law of Moses and in 15:56 that the power of $\sin$ is the law.

3 James D. G. Dunn, The Cambridge Companion to St. Paul (Cambridge: CUP, 2003): 11. Cf. Christopher M. Tuckett, 'Paul, Scripture and Ethics: Some Reflections', NTS 46 (2000): 403-24: 'The OT plays a rather subsidiary role in Paul's ethic (though there has been a strong upsurge of support in recent years for the opposite view).'

4 This article builds upon William Andrew Williamson, 'The Influence of You Shall Not Murder on Paul's Ethics in Romans and 1 Corinthians' (Ph.D. diss., University of Western Sydney, 2007). See Rosner, Paul and the Law, 194-96 for a brief treatment of the influence of the murder commandment in Romans.

5 Generally speaking, quotations of Scripture are less frequent in the more practical sections of Paul's letters; Paul has no need to appeal to the authority of Scripture in such contexts, given that he has his own authority to speak on such matters (cf. 1 Cor. 14:37: 'what I am writing to you is a command of the Lord'). More explicit reference to Scripture is demanded when Paul is engaged in polemic against Jews concerning matters of dispute; see, e.g., Rom. 9-11, where more than 30 quotations of Scripture appear. 


\section{The Murder Commandment and Paul's Opposition to Destructive Behaviour}

Underscoring the seriousness of antisocial behaviour by branding it as tantamount to murder was a common literary device in ancient Judaism. Indeed, murder as a metaphor for antisocial vices was commonplace in Paul's Jewish inheritance. We may illustrate with a range of texts from the biblical prophets, the Psalms and Proverbs, and also some postbiblical Jewish authors.

Isaiah 1 opens with the accusation 'your hands are full of blood' (Isa. $1: 15)$. This is reinforced with a reference to sins 'like scarlet' $(1: 18)$ and identification of the residents of Jerusalem as 'murderers' (1:21). While the LORD expects justice, he sees only bloodshed and hears only a cry (5:7). Yet he promises to wash away 'the bloodstains' of Jerusalem (4:4). ${ }^{6}$ However, Isaiah's concern is not limited to murder per se, but is focused on Jerusalem's neglect of justice and her oppression of society's most vulnerable - the orphan, the widow, and the poor $(1: 17,23 ; 3: 14$ 15; 10:1-2; see also 9:17-21). Murder or bloodshed is not only meant literally, but also figuratively. It dramatises the nature of everyday oppression. A serious murder charge is not easily brushed aside. It shocks and provokes reflection.

Many injustices are spelled out in Isaiah 58 but are then referred to more succinctly in Isaiah 59. The charges are accompanied by the language of murder: in 59:3 ('your hands are defiled with blood'), 59:6 ('deeds of violence'), and 59:7 ('they rush to shed innocent blood'). Again, it seems best to read Isaiah's use of murder language as referring to both actual crimes of murder as well as to socio-economic oppression. Isaiah's rhetoric exposes Jerusalem's worthless pretence of religion: the people are committing murder.

Similarly, Micah portrays oppression and injustice with the language of murder. The rulers and chiefs of Israel 'abhor justice and pervert all equity'; they 'build Zion with blood and Jerusalem with wrong. Its rulers give judgment for a bribe, its priests teach for a price, its prophets give oracles for money' (Mic. 3:9-11; see also Mic. 2:1-2); 'they all lie in wait for blood, and they hunt each other with nets ... the official and the judge

\footnotetext{
6 Unless otherwise indicated Scripture quotations are taken from the New Revised Standard Version Bible: Anglicised Edition, copyright (C) 1989, 1995 the Division of Christian Education of the National Council of the Churches of Christ in the United States of America. Used by permission. All rights reserved.
} 
ask for a bribe, and the powerful dictate what they desire; they pervert justice' (Mic. 7:2-3). Micah takes the murder metaphor a step further by calling the leaders of Israel cannibals (Mic. 3:1-3).

Jeremiah, also like Isaiah, sets oppressing the alien, fatherless, and the widow alongside the charge of shedding blood three times in Jeremiah 7:5-6, 22:3, and 22:13-17. Undoubtedly there was bloodshed in Jerusalem, ${ }^{7}$ but like Isaiah, Jeremiah's charge of shedding blood focuses on oppression and injustice.

In a similar manner Ezekiel 22 sums up Judah's sins as 'shedding blood' (Ezek. 22:2,6,13), or bloodshed and idolatry (vv. 3,4). Lists follow with a wide range of sins, of which the following are closest to murder: oppressing the alien and mistreating the orphan and widow (v. 7); slander by the bloodthirsty (v. 9); bribes to shed blood (v. 12); the demand for advance interest and accrued interest (v. 12); and unjust gain paired with bloodshed (v. 13).

Another list in Ezekiel 22 traces the violent practices of princes, priests, officials, prophets, and the people of the land (vv. 25-29). Like roaring lions, the princes tear their prey, devouring people, taking treasures and precious things, making many widows (v. 25). Priests do metaphorical violence to the law by not teaching it and by disregarding the Sabbath, which strengthens the hands of those who do economic and judicial violence (v. 26). Officials tear their prey like wolves, shed blood, and kill people to make unjust gain (v. 27), while prophets whitewash their deeds (v. 28). And the people of the land practise extortion - getting away with this against resident aliens - commit robbery, and oppress the poor and needy. Both actual murders and oppression explicate the chapter heading, 'the bloody city' (v. 2), and the repeated charges of bloodshed.

In Psalm 94:6 the psalmist affirms God's vengeance will follow the murder of the widow, stranger, and orphan. In Job 24:14, Job laments God's slowness to act when the poor and needy are murdered. In both cases, the murder language is best interpreted as metaphorical for oppression, without excluding actual murder.

In Proverbs 1:8-19 the wise man warns his son about an invitation he will receive from sinners to join them in lying in wait for blood so that they can gain booty. The emphasis on murder is sustained in seven phrases, with greed identified as the motive. ${ }^{8}$ The voice of the sinners is

7 See Jer. 2:30; 5:26; 7:9,31; 19:4; 32:35; 38:4-13 (attempted murder); 41:2.

8 Murder - Prov. 1:11a,b,12a,b,16b,18a,b; greed - Prov. 1:13,19. 
articulated by the wise man who uses their speech to expose their brutality and greed. Of course, greed and evil companionship do not always lead to murder, but murder language is appropriate for the behaviour it describes, the injury it may cause, and the guilt it may incur.

In De specialibus legibus 3.204 Philo calls taking tools from a worker murder and places it under the heading of the murder commandment: 'He who deprives a man of the instruments of living is proceeding towards murder ( $\dot{\varepsilon} \pi$ ' $\dot{\alpha} v \delta \rho o \varphi o v i ́ \alpha v)$, entertaining the idea of plotting even against life. ${ }^{9} \mathrm{He}$ cites Deuteronomy 24:6, which suggests this very thing: 'No one shall take a mill or an upper millstone in pledge, for that would be taking a life in pledge. ${ }^{10}$

Ben Sira also labours to expose social injustice as murder:

The bread of the needy is the life of the poor: whoever deprives them of it is a murderer. To take away a neighbour's living is to commit murder; to deprive an employee of wages is to shed blood. (Sir. 34:25-27) ${ }^{11}$

1 Corinthians contains two examples where Paul likewise treats social sin as metaphorical murder. In 1 Corinthians 1-4 Paul warns the Corinthians that their worldly conception of Christian discipleship is producing antisocial vices and that this has the potential to destroy the community (3:16-17). Strikingly, he calls it destroying the temple, because God's Spirit lives in them. Destroying a temple is an image that connotes both sacrilege and human slaughter. A temple symbolises a people. To sack a temple is to destroy a people, which involves killing and exiling many of them. With this image, Paul warns that something sacrilegious and murderous could take place:

Do you not know that you are God's temple and that God's Spirit dwells in you? If anyone destroys God's temple, God will destroy that person. For God's temple is holy, and you are that temple. (1 Cor. 3:16-17)

In the terms of our investigation, Paul portrays teachers who do violence against the purity of the church by corrupting it with teaching that leads

\footnotetext{
9 Tr. C. D. Yonge, The Works of Philo Judaeus (London: H. G. Bohn, 1854-55).

10 See also 1 En. 99.15 and 100.7 for the explication of oppression as murder.

11 Cf. the close parallel in Jas 5:4-6. Both texts look back to Lev. 19:13: 'You shall not defraud your neighbour; you shall not steal; and you shall not keep for yourself the wages of a labourer until morning.'
} 
to antisocial vices (and other sins) in such a way that the church is destroyed. Paul treats the destructive offence as 'sacrilege'. ${ }^{12}$

Murder defiles God's land, which is a kind of sacrilege (see section 3 below). Here Paul is extending that concept to include the effect of teachers who promote antisocial vices in the church: they corrupt the church, degrading church members and themselves with the stain of murder on account of the antisocial vices. The crime of the teachers is comparable to the destruction of a people and their temple by enemies. As surely as God punishes a murderer, he will punish those who corrupt his people with teaching that produces the antisocial vices.

There is a second case of destruction (involving a different Greek word) in 1 Corinthians that is thematically linked to the first. In 1 Corinthians 8:11-13 Paul states the case against the strong brother or sister who is so puffed up with pride over their knowledge $(8: 1)$ that they wound a weak brother or sister, causing them to stumble, which in the end destroys them. This is a (metaphorical) murder charge aggravated by the unfair advantage of the powerful person against the weak brother or sister. Rather than use his strength to help the poor, he used his strength to defile and kill the poor person, one for whom Christ died. The Scriptures are replete with prophets inveighing precisely against this sort of oppression. Now the same thing is happening in Corinth.

The distinction between the strong and the weak in the church of God in Corinth was both socio-economic and cognitive with respect to knowledge about idols. The strong and well-to-do held to one God and Christ as Lord. They considered idols nothing and freely ate the meat associated with offerings to pagan deities. However, the believing poor still felt the spiritual power of idolatry and could not eat such meat without compromising their loyalty to Christ and again coming under the power of the pagan gods. Paul did not object to the knowledge of the strong, ${ }^{13}$ but he understood the limitation of the weak not to be able to enter into that knowledge. They were unable to eat food associated with pagan gods without polluting their self-awareness.

With respect to the theme of murder, we note the following. Paul uses violent metaphors to describe the behaviour of the knowing against the

12 L. S. Thornton, The Common Life in the Body of Christ ( $3^{\text {rd }}$ edn; London: Dacre Press, 1950): 14. Cited by Anthony C. Thiselton, The First Epistle to the Corinthians: A Commentary on the Greek Text (Grand Rapids: Eerdmans, 2000): 316.

13 He did, however, have a different notion of knowledge that qualified their notion. Thiselton, The First Epistle, 620-31. 
weak, raising the stakes in highly emotive terms: they 'wound ( $\tau$ $\pi \tau o v \tau \varepsilon \varsigma$, v. 12, also strike or beat) ${ }^{14}$ their conscience when it is weak'; they cause them to fall ( $\sigma \kappa \alpha v \delta \alpha \lambda i \zeta \varepsilon 1, v .13)$; by the knowledge of the

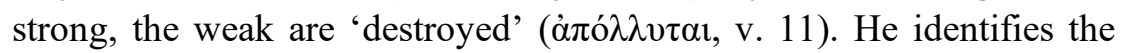
weak person as 'the brother or sister on account of whom Christ died' (v. 11). In verse 13 Paul warns that the offence affects a brother ( $\tau$ òv $\alpha \delta \varepsilon \lambda\left({ }^{\prime} v\right)$. Intriguingly, a sibling relationship being violated recalls the word $\alpha \dot{\alpha} \varepsilon \lambda \varphi \cos _{\text {, }}$ repeated seven times in the story of Cain's murder of Abel in LXX Genesis 4.

That Christ died to cleanse and save the brother or sister that 'the knowing' are defiling and destroying places 'the knowing' in Corinth on the side of Christ's murderers. Paul's charge identifies the crime against the weak brothers and sisters with the crime against Christ: 'sinning against your brothers and wounding their weak conscience, you sin against Christ' (v. 12). ${ }^{15}$ This reflects the union of Christ with his followers. ${ }^{16}$ It is the same idea as is found in 1 Corinthians 3:16-17, 'where to damage a fellow Christian is to commit the sacrilege of profaning God's temple sanctified by the Spirit'. ${ }^{17}$ At this point, the two warnings against metaphorical murder in 1 Corinthians are linked.

There are two cases of metaphorical murder in 1 Corinthians: the promotion of antisocial vices by the worldly teachers in Corinth and 'the knowing' building up the weak to their destruction. Paul evoked the Jewish tradition of metaphorical murder, an extension of the murder commandment, in order to expose the nature and gravity of the sin involved and to show just what was at stake in the issue: the very existence of the church in Corinth and the individual's strength of faith before God.

\section{The Murder Commandment and Paul's Opposition to Reviling}

The term 'reviler', $\lambda$ oídopo $\varsigma$, appears in the vice lists of 1 Corinthians 5:11 and 6:9-10. Reviling is a term that fits with Paul's vivid descriptions

14 The verb connotes the infliction of actual damage, not mere hurt feelings. Thiselton, The First Epistle, 620-31.

15 Our literal translation.

16 See Acts 9:4 where Christ says to the persecutor 'Why do you persecute me?' Thiselton, The First Epistle, 655-56.

17 Thiselton, The First Epistle, 656. 
in chapters 1-4 of the strife, jealousy, factions, quarrelling, arrogance, and boasting that plagued the church of God in Corinth. It is also a vice frequently related to murder in biblical and Jewish tradition.

In a range of Jewish texts murder language is frequently associated with malicious speech, whether or not actual killing is involved. False speech as a murder weapon is firmly established in the Pentateuch in three places: Exodus 23:7, Deuteronomy 19:15-21, ${ }^{18}$ and Leviticus 19:16. It is not easy to distinguish actual murder from metaphorical murder by the tongue. In Ezekiel 22:9 the prophet says of those in Jerusalem: 'In you are those who slander to shed blood.' Slander is reckoned as murderous in many texts in the Psalms and in the Apocrypha. ${ }^{19}$ Likewise, this is also the case in many stories from Jewish history as told by Josephus, as well as in other Jewish texts. ${ }^{20}$ Lying and proud speech can also be murderous: ${ }^{21}$

For I hear the whispering of many - terror all around! - as they scheme together against me, as they plot to take my life ... Let the lying lips be stilled that speak insolently against the righteous with pride and contempt. (Ps. 31:13,18)

Moreover, there are biblical and Jewish traditions that specifically relate

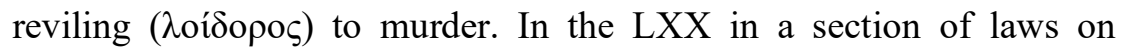
violence, headed by a subsection on murder (Exod. 21:12-31), a law

18 The lex talionis punishment for false witness in v. 21 is 'life for life', which suggests a case in which a false witness has attempted to get a person judicially killed. The suggestion of murder is strengthened by its context in Deuteronomy, following a long discussion of murder (19:1-13) with which it is linked by the same injunction: to 'show no pity' $(19: 13,21)$.

19 Ps. 5:6,9; 7:14; 27:12; 31:20; 35:20; (50:19-20); 52:1-7; 57:4; 58:1-6; 59:12-13; 64; $69: 4 ; 94: 21 ;(101: 5,7) ; 109: 2-6 ;(119: 69) ; 120 ; 140: 3,9,11$. References in parentheses are less explicitly murderous, but arguably evoke the murder metaphor nonetheless. Sir. 28:12-26; 21; 51:1-12; 2 Macc. 4:1; 3 Macc. 2:25-26; 3:2, cf. 3:22-24.

20 Slander in relation to murder plays a huge role in Josephus, as is evident from this long list of references that carry a double reference to both slander and murder: A.J. $6: 267,285-86 ; 10: 252 ; 11: 275 ; 13: 303,310 ; 15: 81,213,220,229 ; 16: 8,9,69,81,85$, $112,189,200,208,219,255,265,266,269,303,311,313,352,399,471,472,475,480$, 482, 487, 493, 495, 552, 564, 569, 611, 633, 634, 637; B.J. 1:72, 77, 360, 443, 448, 450, 451, 452, 469; 7:41, 56, 443; C. Ap. 1:219. See also Test. Isaac 4:50: 'Do not kill with the sword, do not kill with the tongue' (tr. W. F. Stinespring, Old Testament Pseudepigrapha (OTP), ed. James H. Charlesworth, 2 vols. (New York: Doubleday, 1983, 1985): 1:908); 2 En. 60:1: 'How it is not proper to kill a human being, neither by weapon, nor by tongue' (tr. F. I. Anderson, OTP 1:186); and the slander of Pharaoh's son in Jos. Asen. 24:7-10.

21 For example, see in context Ps. 12:2-4; 17:8-12; 31:18; 56:2; 59:7,12; 73:6,8; 86:14; 94:2,4-7. Ahiqar 99 warns that 'the treachery of the mouth is more dangerous than the treachery of battle' (tr. J. M. Lindenberger, OTP 2:500). 
anticipates $^{22}$ that reviling will sometimes provoke blows that lead to death (Exod. 21:18, cf. 2 Macc. 12:14). Indeed, the people revile Moses and are ready to stone him (Exod. 17:2,4; cf. Num. 20:3). Ben Sira twice warns that reviling can lead to murder: 'The vapour and smoke of the furnace precede the fire; so insults ( $\lambda$ ot $\delta$ opíal) precede bloodshed' (Sir. 22:24); 'The strife of the proud leads to bloodshed, and their abuse ( $\delta 1 \alpha \lambda o เ \delta$ ó $\eta \sigma 1 \varsigma)$ is grievous to hear' (Sir. 27:15).

In Josephus a reviler frequently provokes murder. Thus Mariamne reviled Herod, his sister, and his mother unceasingly, which contributed to Herod executing her (B.J. 1.438, 477). Mariamne's two sons by Herod hated their father for murdering their mother, so they reviled him (A.J. $16.69,363 ;$ B.J. 1.540 ), which led eventually to Herod executing them. Herod's son Antipas forged a letter in which Herod's sister reviled Herod (B.J. 1.642). Antipas did so in order that Herod would be provoked to execute her, which he almost did, except that the letter was found out to be a forgery. The Jewish people twice reviled Pilate for taking money from the temple for an aqueduct, which Josephus says provoked him to slaughter many of them (A.J. 18.60-61) ${ }^{23}$ Likewise they reviled the Roman general Florus, which Josephus says led to a massacre of Jews (B.J. 2.295, 302). Josephus was himself reviled by John of Gischala, his arch-enemy who more than once sought to kill him. ${ }^{24}$

By way of explanation, in early Jewish moral teaching antisocial vices can serve as synecdoches for murder. Ben Sira writes an extended wisdom paragraph on anger, wrath, and vengeance in which he mentions many related antisocial sins and vices: harbouring anger, having no mercy, harbouring wrath, enmity, being angry with one's neighbour, strife, being hot-tempered, disrupting friendships, sowing discord (or slander), obstinacy, hasty quarrelling, a hasty dispute (27:30-28:11). At the end of his paragraph all these antisocial vices reach their climax: bloodshed (28:11). Such a conclusion was already intimated by the opening reference to anger and wrath as 'abominations' (27:30), which is a likely reference to the moral impurity of murder. He can call anger and wrath abominations because, as antisocial vices integral to murder,

\footnotetext{
22 The law here is not only prescriptive but descriptive of social reality.

23 The practice of antisocial vices may not only lead to murder but may also lead to being murdered, as in the case of the Galileans reviling Herod, and, again, the Jews reviling Florus.

24 B.J. 6.98, 108; Vita 82, 95, 122, 123, 125, 189.
} 
anger and wrath can serve as synecdoches for murder, which finally appears at the end of the paragraph (28:11).

Ben Sira counsels: 'Remember the commandments, and do not be angry with your neighbour; remember the covenant of the Most High, and overlook faults' (28:7). The commandments and covenant may refer either to the Decalogue or the Torah generally. The words 'do not be angry with your neighbour' and 'overlook faults' not only recapitulate the theme of the paragraph presented in the first two verses (Sir. 27:3028:1), but allude to Leviticus 19:17-18 in the LXX. ${ }^{25}$ Below we make the case that Leviticus 19:17-18 contains an application of the murder commandment. Like Leviticus 19:17-18, Ben Sira is reflecting on the covenant commandment which forbids the sin that anger and vengeance produce. When he says 'no anger, no wrath, no vengeance, and overlook faults', he seems to be reflecting on the murder commandment, in effect saying 'do not sow the seed of murder'. Ben Sira gives antisocial vices a synecdochal role pointing to murder because they are the active ingredients in murder. In another paragraph on gossip and slander (Sir. 28:12-26), Ben Sira hypostasises them and attributes to them the murderous effect they produce. Thus, antisocial acts (gossip and slander) shake, pillage, and devastate humanity (Sir. 28:14,18-20,26).

Aristeas recognises a king's anger as the equivalent of murder on account of a monarch's absolute power. '[For kings] any recourse to anger brings death' (Let. Aris. 253). ${ }^{26}$ A similar practical equivalence is pronounced by a Jewish sibyl: 'Bridle wild anger, for often one who struck a blow unintentionally committed murder' (Sib. Or. 2.129-30). ${ }^{27}$ In these two quotations anger and wild anger are presented as murderers. It is apparent then that Jesus's interpretation of the murder commandment as forbidding anger and insults and commanding reconciliation (Matt. 5:21-22) was not novel. Rather, Jesus's words drew upon deeply rooted Jewish and biblical traditions, which freely substituted related vices for what the murder commandment forbade. ${ }^{28}$

In a text from the Judean desert, an author now designated 'Pseudo Moses's refers to Israel's transgressions in terms that appear to be synecdoches for Decalogue commandments. He writes: 'striving for

25 The first of the two phrases is verbally close to Lev 19:18bc; the second, 'overlook faults', is thematically close to Lev. 19:18a ('you shall not take vengeance').

26 Tr. R. J. H. Shutt, OTP 2:29.

27 Tr. J. J. Collins, OTP 1:348.

28 On the image of God (Gen. 9:6b) and insult, anger, and malice - synecdoches of murder related to Gen. 9:6a - see 2 En. 44:1-4. 
wealth and gain [and ... on]e stealing that which is his fellow's, and one oppressing another. They will pollute my Sanctuary [profane my Sabbaths]' (4Q390, Fr. 2, 544). ${ }^{29}$ These sins reflect the commandments against coveting, stealing, murder, taking the LORD's name in vain, and the commandment concerning Sabbath observance. Thus, the phrase 'one oppressing another' draws upon the tradition of calling social injustice murder and refers obliquely with the other sins to the Decalogue, specifically to the murder commandment.

Lines 3-8 of Pseudo-Phocylides offer an abbreviated rendition of Decalogue content ${ }^{30}$ in which the murder commandment is represented as follows: 'Neither devise treachery nor stain your hands with blood'. ${ }^{31}$ Both halves of line 4 work together to represent the murder

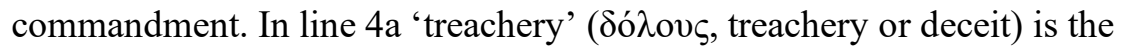
antisocial vice that provides the evidence that a killing is murder (see $\delta$ ó $\lambda \omega$ in Exod. 21:14). In line 4b 'staining one's hands with blood' refers to the pollution of murder. ${ }^{32}$ The word $\delta$ '́ $\lambda$ o $\varsigma$ - as a constitutive part of murder - represents the murder commandment either as the antisocial vice (treachery) that leads to murder, or the antisocial vice (deceit) that is the instrumental to murder.

Turning to 1 Corinthians, while the jury is still out on the precise nature of the problems that led to the divisions in the church in terms of socio-historical background, Bruce Winter's study of rhetoric in firstcentury Corinth provides crucial background for understanding what $\lambda$ oídopo $̧$ might have meant in Corinth. ${ }^{33}$ It is possible that Apollos's own

29 Tr. Géza Vermès, The Complete Dead Sea Scrolls in English (rev. edn; London: Penguin, 2011). Brackets indicate damaged manuscript.

30 On Pseudo-Phocylides's use of the Decalogue and other pentateuchal material, see K.-W. Niebuhr, Gesetz und Paränese: Katechismusartige Weisungsreihen in der frühjüdischen Literatur (WUNT 2 28; Tübingen: Mohr Siebeck, 1987): 5-31.

31 Tr. P. W. van der Horst, OTP 2:574.

32 Cf. similar expressions: Gen. 9:5; Deut. 21:7; Isa. 1:15; 59:3; Ezek. 22:2,13; 23:3637.

33 B. W. Winter, Philo and Paul Among the Sophists: Alexandrian and Corinthian Responses to a Julio-Claudian Movement (rev. edn; Grand Rapids: Eerdmans, 2002). Some scholars have expressed doubts about Winter's reconstruction. J. MurphyO'Connor, 'Review of Winter, Philo and Paul among the Sophists', RevBib 110 (2003): 428-33, for instance, is not convinced that the sophists were a major force in first-century Corinth. While he agrees that there is good evidence for their presence in Alexandria, the evidence for Achaia and Corinth is lacking. Much of Winter's contribution, however, does not depend on the specific identification of the influence of the sophistic movement on the Corinthian Christians. The sophistic movement was on the rise in Alexandria, a very influential city, at least, and key cities in the Empire were porous when it came to the movement of people and ideas. But whether or not the sophists were the culprits is 
use of rhetoric at Corinth had incited sophist-style factionalism. ${ }^{34}$ Winter argues that Paul's discussion of wisdom in chapters $1-4$ is in fact a pointby-point refutation of aspects of sophistic behaviour. When sophists came into a city they broadcast their own repute, extemporised in impressive oral displays, and used persuasive rhetoric with great flair. ${ }^{35}$ The 'spin doctors' of their day, the sophists' aim was to inspire a particular commitment and zeal for themselves amongst their disciples. ${ }^{36}$ What Paul accuses the Corinthian Christians of, namely 'quarrels' and 'jealousy' $(1: 11 ; 3: 3)$, were actually terms for sophistic discipleship. ${ }^{37}$

Regarding the use of $\lambda$ oídopos terminology in 1 Corinthians: another ancient text describes how the insults ( $\lambda$ oroopíal) from a disciple of the sophist Chrestus directed toward the sophist Hadrian so incensed the disciples of Hadrian that his pupils gave orders to their slaves to thrash the reviler, which resulted in his death. ${ }^{38}$ Sophist education cultivated rivalries which predictably resulted in one group and its leader reviling another and vice versa. Dio Chrysostom visited Corinth from 86-94 CE and wrote about the sophists there in his eighth Oration (De virtute 8.9): 'That was the time, too, when one could hear crowds of wretched sophists around Poseidon's temple shouting and reviling

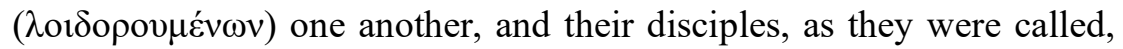
fighting with one another.' 39

In 1 Corinthians, it is noteworthy that Paul and the other apostles are reviled by their enemies ( $\lambda$ otoopov́ $\mu \varepsilon v o r ; 1$ Cor. 4:12); elsewhere in the New Testament those who will kill Christ 'revile' him (John 9:28; 1 Pet. 2:23). Paul describes himself and the other apostles as living under a sentence of death (4:9) whilst being 'beaten', 'reviled', 'persecuted', and 'slandered' (4.11-13). As such, he is an imitator of Christ crucified (4:1617), who was also under a sentence of death and reviled. The reviling of Christ is not mentioned in 1 and 2 Corinthians, but it is nonetheless a

less the point than simply that the church in Corinth was clearly in the thrall of human rhetoric, with its elevation of human brilliance and tendency to feed competition and pride.

34 Winter, Philo and Paul among the Sophists, 177-78.

35 Winter, Philo and Paul among the Sophists, 144-47.

36 Winter, Philo and Paul among the Sophists, 185-87.

37 Winter, Philo and Paul among the Sophists, 175-76.

38 Philostratus, Eunapius, Lives of the Sophists. Eunapius: Lives of the Philosophers and Sophists, tr. Wilmer C. Wright (LCL 134; Cambridge, Mass.: Harvard University Press, 1921): 228-29. Cited by Winter, Philo and Paul among the Sophists, 126, 172.

39 Dio Chrysostom, Discourses 1-11, tr. J. W. Cohoon (LCL 257; Cambridge, Mass.: Harvard University Press, 1932). 
well-known tradition about Christ (see 1 Pet. 2:23; John 9:28; cf. Rom. 15:3); the apostles' identification with Christ and the cross is the subplot of 1 Corinthians 4:1-17. Since in 1 Corinthians Paul demonstrates how his life conforms to Christ, and he lays a large emphasis on Christ crucified, Paul may well presume that people would connect the reviling of himself and the apostles with the reviling of Christ. For both of them, reviling and being put to death were only a short step apart.

That Paul links his account of being reviled to persecution and being under a sentence of death suggests that reviling may be associated with murder in 1 Corinthians. And Paul's indebtedness to the commandment not to murder may well stand behind his opposition to reviling.

\section{The Murder Commandment and Purity Concerns}

A third area of possible influence of the murder commandment in 1 Corinthians concerns the conception of murder as moral impurity. Jonathan Klawans's exploration of the relationship between impurity and $\sin$ in the Jewish Scriptures and in ancient Judaism draws conclusions that clarify the place of murder in Paul's symbolic world. Building on the work of Hoffman, Milgrom, Frymer-Kensky, and Wright, and the neglected tradition of Büchler, Klawans identifies three main conceptions of impurity in the Jewish Scriptures: food impurity, ritual impurity, and moral impurity ${ }^{40}$ It is the third category that relates to murder in 1 Corinthians.

In the Jewish Scriptures, acts of moral impurity are so reprehensible that they defile or downgrade the status of offenders and the land. These acts include sexual sins (Lev. 18:24-30; see also Num. 5:11-31), idolatry (Lev. 19:31; 20:1-3), and bloodshed (Num. 35:33-34). Moral impurity is distinguished from ritual impurity by being called an 'abomination' that 'pollutes' the land. They pollute (or degrade) the sinner, the land, and the sanctuary and lead eventually to expulsion from the land (Lev. 18:28; Ezek. 36:19). ${ }^{41}$

According to Torah impurity laws, not only do sexual immorality and idolatry defile, but murder also defiles the murderer, the sanctuary, and

40 J. Klawans, Impurity and Sin in Ancient Judaism (Oxford: OUP, 2000): 21. Building on Klawans' work, Christine Hays proposes that genealogical impurity is a further category. See C. E. Hayes, Gentile Impurities and Jewish Identities: Intermarriage and Conversion from the Bible to the Talmud (Oxford: OUP, 2002): 58-59, 68-91.

41 Klawans, Impurity and Sin, 26. 
the land (Num. 35:9-34; Deut. 19:1-13). The sanctuary and land are only cleansed through blood, that is, the execution of the murderer. The impurity of murder is an important dimension to the theme of murder for understanding the murder commandment and murder texts. We observe that moral impurity, as a subsystem of the Jewish faith, functions as a supporting structure or overlapping system to Decalogue ethics, not as competition. This is especially evident in the prophetic allusions to Decalogue traditions in Hosea 4:1-2 and Jeremiah 7:9. Both are invoked in relation to preserving God's people in the land (Hos. 4:1 and 3; Jer. 7:7), which otherwise is polluted by the covenant violations. ${ }^{42}$

Murder as moral impurity often appears alongside idolatry and sexual immorality in the Scriptures and post-biblical Jewish writings. Table 1 gives a sense of the distribution of sins identified in context in relation to impurity in the Scriptures, Second Temple Jewish writings, and the nonPauline NT.

Table 1: Examples of Moral Impurity Involving Idolatry, Sexual Sin and Murder

\begin{tabular}{lccc} 
Text & Idolatry & Sexual Sin & Murder \\
\hline Lev. 18:24-30 & $\mathrm{X}$ & $\mathrm{X}^{43}$ & $(\mathrm{X})^{44}$ \\
Lev. 20:1-23 & $\mathrm{X}^{45}$ & $\mathrm{X}^{46}$ & $(\mathrm{X})^{47}$ \\
Deut. 18:9-12 & $\mathrm{X}^{48}$ & & $(\mathrm{X})^{49}$ \\
1 Kgs 14:23-24 & $\mathrm{X}$ & $\mathrm{X}^{50}$ & + \\
2 Kgs 16:3-4 & $\mathrm{X}$ & + & $(\mathrm{X})^{51}$ \\
Ps. 106:36-40 & $\mathrm{X}$ & $(\mathrm{X})^{*}$ & $\mathrm{X}$ \\
Prov. 6:16-19 & & & $\mathrm{X}$ \\
Jer. 2:4-3:5 & $\mathrm{X}$ & $(\mathrm{X})^{*}$ & $\mathrm{X}$
\end{tabular}

42 K. Berger, Die Gesetzesauslegung Jesu. Pt 1, Markus und Parallelen (WMANT 40; Neukirchen-Vluyn: Neukirchener Verlag, 1972): 296.

43 Includes incest, bestiality, homosexuality.

44 Giving offspring in sacrifice to Molech.

45 Includes turning to mediums and spiritists.

46 Includes adultery, incest, bestiality, homosexuality.

47 Giving offspring in sacrifice to Molech.

48 Passing children through the fire, soothsayer, augur, sorcerer, cast spells, consulting ghosts or spirits, seeking oracles from dead.

49 Passing children through fire.

50 Male shrine prostitution.

51 Passing children through fire. 


\begin{tabular}{|c|c|c|c|}
\hline Text & Idolatry & Sexual Sin & Murder \\
\hline Jer. 7:9-15 & $\mathrm{X}$ & $\mathrm{X}$ & $\mathrm{X}$ \\
\hline Jer. 7:30-31 & $\mathrm{X}$ & & $X^{52}$ \\
\hline Jer. 16:18 & $\mathrm{X}$ & & \\
\hline Jer. 19 (see vv. 4,5,13) & $\mathrm{X}$ & & $X^{53}$ \\
\hline Jer. 32:34-35 & $\mathrm{X}$ & & $X^{54}$ \\
\hline Ezek. 7:4,9,19-23 & $\mathrm{X}$ & & $X$ \\
\hline Ezek. 8-9 & $\mathrm{X}$ & & $\mathrm{X}$ \\
\hline Ezek. 20:30-31 & $\mathrm{X}$ & & $(\mathrm{X})^{55}$ \\
\hline Ezek. 22 & $X$ & $\mathrm{X}^{*}$ & $\mathrm{X}$ \\
\hline Ezek. 23:36-39 & $X^{56}$ & $X^{* 57}$ & $\mathrm{X}$ \\
\hline Ezek. 33:25-26 & $\mathrm{X}$ & $\mathrm{X}$ & $\mathrm{X}$ \\
\hline Ezek. 36:18 & $\mathrm{X}$ & & $X$ \\
\hline Hos. $4: 1-3^{58}$ & $(\mathrm{X})$ & $\mathrm{X}$ & $\mathrm{X}$ \\
\hline Hos. 5:3-4 (4:17-19) & $\mathrm{X}$ & $(\mathrm{X})^{*}$ & \\
\hline Hos. 6:7-10 & $\mathrm{X}$ & & $\mathrm{X}$ \\
\hline Ezra $6: 21 ; 9: 1-3,10-12$ & + & + & + \\
\hline Jub. 1:8-12 & $\mathrm{X}$ & & $\mathrm{X}$ \\
\hline Jub. 7:20-33 & & $\mathrm{X}$ & $\mathrm{X}$ \\
\hline Jub. 11:2-6 & $\mathrm{X}$ & & $\mathrm{X}$ \\
\hline Jub. 16:5-6 & & $X$ & \\
\hline Jub. 20:5-8 & $\mathrm{X}$ & $\mathrm{X}$ & $\mathrm{X}^{59}$ \\
\hline Jub. $21: 5 ; 18-20$ & $\mathrm{X}$ & & $\mathrm{X}$ \\
\hline Jub. 33:19-20 & & $\mathrm{X}$ & \\
\hline 1 En. 9:8; 10:11 & & $\mathrm{X}$ & \\
\hline
\end{tabular}

52 Burning children in fire.

53 Burning children in fire.

54 Offering children to Molech.

55 Passing children through fire.

56 Idolatry, offering children as food to idols, slaughtering children for idols.

57 Adulteries.

58 The indication of moral defilement here is 'the land mourns'.

59 Reference to judgement of giants for violence. 


\begin{tabular}{lccc} 
Text & Idolatry & Sexual Sin & Murder \\
\hline 1 En. 12:4-6 & & $\mathrm{X}$ & $\mathrm{X}$ \\
1 En. 15:3-4 & $\mathrm{X}$ & $\mathrm{X}$ & $\mathrm{X}$ \\
1 En. 19:1-2 & & $\mathrm{X}^{60}$ & $\mathrm{X}$ \\
Matt. 15:18-20 & & $\mathrm{X}$ \\
Matt. 23:25-35 & & $\mathrm{X}^{61}$ & $\mathrm{X}$ \\
Mark 7:21 & $\mathrm{X}$ & $\mathrm{X}$ & $\mathrm{X}$ \\
Acts 15:20,19; 21:25 & $\mathrm{X}$ & $\mathrm{X}^{62}$ & $\mathrm{X}$ \\
Rev. 21:8 & $\mathrm{X}$ & $\mathrm{X}^{63}$ & $\mathrm{X}$ \\
Rev. 22:14-15 & & &
\end{tabular}
Key
$\mathrm{X} \quad$ indicated in text (not necessarily with just this word)
(X) probably indicated in text
$+\quad$ implied, but not explicit
* the sexual language may be metaphorical for idolatry or even refer to both sexual immorality and idolatry

Paul's familiarity with and use of this triad is clear from his treatment of pagan $\sin$ in Romans 1:18-32. Three groupings of sin are evident. Those in 1:21-23,25 and 1:24,26-27 are clearly related to idolatry and sexual immorality respectively. The third grouping in 1:28-32 might be termed antisocial vices. However, the explicit mention of 'murder' in verse 29 , coupled with the fact that many of the vices have established associations with murderous violence in the Scriptures or Jewish writings, suggest that murder as a metaphor for oppression and other antisocial sins is the essence or focus of the list. Vices in Romans 1:28-32 that do not directly point to the crime of murder, such as disobedience to parents (v. 30), nonetheless point to an injustice that violates other humanward commandments. Our argument is not that the crime of murder alone is presented here, but that the broad sense of the murder theme may represent all sins against the neighbour. ${ }^{64}$

\footnotetext{
60 Adultery, fornication.

61 Fornication, adultery, licentiousness.

62 Fornicators.

63 Fornicators.

64 See above on murder as the quintessential antisocial sin. Cf. P. Stuhlmacher, Paul's Letter to the Romans: A Commentary, tr. S. J. Hafemann (Louisville: Westminster John
} 
Turning to 1 Corinthians, a growing number of scholars point to pervasive purity concerns as driving much of Paul's instruction in 1 Corinthians. Concern about purity issues is to be expected in a situation where the infiltration of outside influences is believed to have deleterious effects on the health of the worshipping community. ${ }^{65}$ As David deSilva argues, the gospel had a significant transforming effect on Christian thinking about purity issues, but ' $[\mathrm{h}]$ oliness and purity both still require boundaries to be drawn and maintained between the surrounding culture and the Christian group'. ${ }^{66}$

Indeed, Paul's description of the Corinthian Christians in 1 Corinthians 1:2a shows his hand early in the letter in this regard. Paul alludes three times to their holy status: they are the 'church of God', a possessive genitive; 'sanctified in Christ Jesus'; and called to be his holy people. Also, 1 Corinthians 1:2b identifies them as a worshipping community, those who 'call on the name of our Lord Jesus Christ'. Paul writes to call the Christians in Corinth to live in accordance with their identity as the holy people of God.

In 1 Corinthians purity issues are reflected in the identification of the readers as the temple of God (3:17) and the discussion of the moral implications of that understanding. The command to 'clean out the old yeast' (5:7) and to 'drive out the wicked person' from their midst (5:1113) reflects the language of purity concerns, and Paul's command to avoid prostitutes is based on the radical impurity which that would bring to their Spirit-indwelt temple (6:16-19). Purity concerns are also reflected in the issue of the children's uncleanness or holiness based on the status of the unbelieving husband (7:14) and in the concern not to provoke the Lord by drinking from both his cup and those of demons (10:21-22). 'Much of Paul's use of purity terminology', Michael Newton points out, 'centers upon his view that the believers constitute the Temple of God and as such enjoy the presence of God in their midst', and if that

Knox, 1994). His proposal is that the violation of all the second table justice commandments are represented by the vices of Rom. 1:29-31. The vice lists of 2 Cor. 12:20-21, Col. 3:5,8, and Gal. 5:19-21 similarly bear the marks of the three sins understood as headings or synecdoches for Gentile impurity.

65 As pointed out by J. M. Lieu, Christian Identity in the Jewish and Graeco-Roman World (New York: OUP, 2004): 104, '[t]he need to observe sacred boundaries, variously articulated, but in Judaism particularly through food and purity laws and the structuring of the Temple, correlates with the importance laid on well-defined and well-protected social boundaries.'

66 D. A. deSilva, Honor, Patronage, Kinship and Purity: Unlocking New Testament Culture (Downers Grove: InterVarsity, 2000): 294. 
presence is to remain with them, they must maintain the purity of the community. ${ }^{67}$ The broader issue of the influence of Corinthian cultural values and behaviours within the church of that city is to be understood as a fundamental concern for the purity of the worshipping community. ${ }^{68}$

In this connection Ciampa and Rosner have argued that in the central section of 1 Corinthians Paul deals with two principal Gentile vices of sexual immorality and idolatry. ${ }^{69}$ In 1 Corinthians 5-7 Paul deals primarily with issues related to sexual immorality, first in a negative treatment of its manifestations in the church in Corinth (4:18-6:20) and then in a positive treatment of marriage and sexual relationships ${ }^{70}$ (ch. 7; note how the chapter is introduced in v. 2 with a reference to $\pi$ opveía.) Chapters 8-14 then deal with the issue of idolatry, beginning, again, with a negative treatment of its manifestations in Corinth $(8: 1-11: 1)$ and then moving to a more positive treatment of the proper worship of the one true God (11-14; note how 12:2 relates the following material back to the issue of idolatry)..$^{71}$

Our exploration of murder as moral impurity suggests a third major purity concern in the letter. We propose that in 1 Corinthians 1-4 Paul addresses the impurity of murder, as represented by antisocial vices. The wisdom of this world that empowers sophistic discipleship in Corinth is destroying or corrupting ( $\varphi \theta \varepsilon i ́ \rho \varepsilon 1,1$ Cor. 3:17) the church with its

67 M. Newton, The Concept of Purity at Qumran and in the Letters of Paul (SNTSMS 53; Cambridge: CUP, 1985): 52.

68 On the temple metaphor and moral exhortation in 1 Cor. see Brian S. Rosner, 'The Church as Temple and Moral Exhortation in 1 Corinthians' in Ecclesia and Ethics: Moral Formation and the Church, ed. E. Allan Jones III, John Frederick, John Anthony Dunne, Eric Lewellen, and Janghoon Park (London/New York: Bloomsbury T. \& T. Clark, 2016): 41-54.

69 See Roy E. Ciampa and Brian S. Rosner, 'The Structure and Argument of 1 Corinthians: A Biblical/Jewish Approach', NTS 52:2 (2006): 205-18 and Roy E. Ciampa and Brian S. Rosner, The First Letter to the Corinthians (Pillar New Testament Commentary; Grand Rapids: Eerdmans, 2010).

70 This arrangement of ethical material is reminiscent of Hellenistic Jewish paraenesis (reported by Niebuhr, Gesetz und Paränese, 232), which discusses sexual deviations, such as incest and homosexuality, and sexual relations in marriage in close proximity.

71 Towards the end of each negative section (5:1-6:20 and 8:1-11:1) Paul provides both negative and positive imperatives using the same language relating to the broader theme. In concluding the negative section on sexual immorality, Paul exhorts the Corinthians to flee from sexual immorality (6:18) and to 'glorify God' with their bodies (6:20). In concluding the negative section on idolatry, Paul exhorts them to 'flee from the worship of idols' (10:14) and to do everything 'for the glory of God' (10:31). See Ciampa and Rosner, 'The Structure' and Ciampa and Rosner, The First Letter for a full defence and exposition. 
antisocial vices. These are represented in Paul's vice lists of 5:11 and 6:9-10 with the term reviler ( $\lambda$ oíoopos).

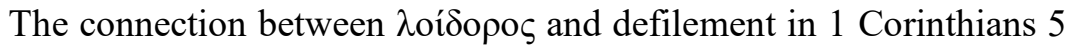
is clear. Paul relies on an analogy between what the Scriptures say about the sins that defile the land, including murder, and what should be done

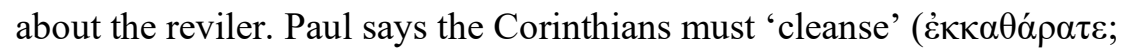

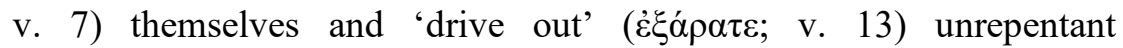
practitioners of impurity from the community, which include the 'reviler' (5:11). Then, the reference to those who teach people the way of antisocial vices - and thereby destroy or corrupt ( $\varphi \theta \varepsilon i ́ p \omega)$ the temple is a reference to temple defilement by a marauder.

As moral purity is concerned with fitness for worship, it emerges that each major section of 1 Corinthians has implications for worship. In chapters 5-7, in place of the defilement of sexual immorality is pure sex exclusive to marriage, producing sanctified children $(7: 14)$. In chapters $8-14$, in place of idolatry is worship according to the Messianic Shema (1 Cor. 8:6), apostolic traditions (1 Cor. 11:2), and gifts of the Spirit for edification $(12: 7 ; 14: 1-5,12)$. Similarly, in chapters $1-4$, in place of the antisocial vices that tear down the temple is Paul, like a skilled master builder, laying the only foundation that can be laid for the temple: Jesus Christ and the cruciform way of life, as taught and lived out by Paul who imitates Christ (1 Cor. 3:10-12; 4:16-17). ${ }^{72}$ Our observations support the thesis that in correcting the Corinthians Paul's goal goes beyond merely dealing with their divisions; rather, his overriding concern is to have them live in accordance with their sanctified status and glorify God in 'temple' worship.

\section{The Murder Commandment and the Centrality of Love}

The fourth and final step in apprehending the influence of the murder commandment in 1 Corinthians is to consider love as the opposite of murder. This link is clear in a range of texts from Paul's Jewish inheritance.

In Leviticus 19:9-18 a broad range of justice related concerns ends with a double climax: allusions to murder and a command to love (cf.

72 On an analysis of the cruciform way of life, see M. J. Gorman, Cruciformity: Paul's Narrative Spirituality of the Cross (Grand Rapids: Eerdmans, 2001). 
v.18: 'You shall not take vengeance or bear a grudge against any of your people, but you shall love your neighbour as yourself: I am the LORD.'). Verses 33-36 are a shortened parallel to verses 9-18, with the pointed function of applying the legislation against oppression of resident aliens (cf. v. 34: 'The alien who resides with you shall be to you as the citizen among you; you shall love the alien as yourself'). In both cases, allusions to the justice commandments concerning social justice - the stealing, coveting, and especially murder commandments - are summed up in the love commandment.

Similarly, murder and love are frequently found together as opposites in Jewish texts. Although in Scripture Jacob escapes Esau's plot to murder him by virtue of God's protections and Jacob acting prudently, ${ }^{73}$ Jubilees draws attention to the need for Jacob and Esau to love one another if they are to avoid murdering each other. In long speeches both Rebekah and Isaac enjoin Esau and Jacob to 'love one another and that one will not seek evil for his brother, but only love him' (Jub. 35.20). ${ }^{74}$ The word 'love' is used three times in Rebekah's last words to Esau, four times in Esau's pledge to do so, and three times in Isaac's last words to his sons, including an allusion to Leviticus 19:18c in Jubilees 36.4. Then, in a climactic speech, Esau renounces love for Jacob and tries to kill him (Jub. 37.18-23).

In the biblical story of Joseph, Joseph demonstrates wisdom, forgiveness, and love, although the word 'love' is not used. However, in the Testaments of Simeon, Dan, and Gad (see T. Sim. 3.4-6; 4:7; T. Dan $6.10 ; 5.1-3$; T. Gad 5.3-7; 6.1,3,4,7), the focus falls on God delivering the brothers from the grip of antisocial vices that caused them to wish to murder Joseph, so that they could love him. In separate confessions Simeon, Dan, and Gad confess to wanting to kill Joseph on account of their jealousy, anger, and hatred. ${ }^{75}$ However, each is led to return to loving God, to renouncing their vices, and to loving their brother.

In the Jewish Scriptures Saul's rivalry with and envy of David makes Jonathan's love for David - his natural rival for the throne - all the more 'wonderful' (2 Sam. 1:26). The expressions of Jonathan's unusual love for David appear often in the text (1 Sam. 18:1-4; 19:1-7; 20; 23:16-18).

\footnotetext{
73 Wis. 10:9-12 attributes his survival to godly wisdom. Jacob put distance and time between himself and Esau; upon his return he offered gifts, the return of blessing, and a show of repentance and submission to Esau.

74 Tr. O. S. Wintermute, OTP 2:123.

75 T. Sim. 2.7; T. Dan 1.4, 8; T. Gad 1.8-9; 2.1-2.
} 
Jonathan's love for David, however, is necessary if the natural course of events is to be averted with David following the typical ancient Near Eastern practice of securing his throne by wiping out the family of his predecessor. Jonathan's rejection of rivalry with David is underscored by an ironic murder motif that links Jonathan and David with Cain and Abel. When David protests his innocence in the face of Saul trying to kill him, Jonathan gives David an invitation: 'Come, let us go out into the field' (1 Sam. 20:11). These words echo Cain speaking to Abel: 'Let us go out to the field"76 (Gen. 4:8). Jonathan, like Cain, seeks a meeting place out of sight from everyone else, and brings weapons (bow and arrows), but his purpose is to prevent a murder and to declare his covenant love.

Pseudo-Philo puts a speech in Jonathan's mouth to dissuade David from future violence or revenge against his family. Jonathan appeals to David on the basis of their covenanted love not to respond in a murderous way to Saul's murderous attacks, but to preserve his family (Liber antiquitatum biblicarum 62.11). Later, in his dying words to David on behalf of his family, Saul appeals to the love of Leviticus 19:17-18: 'Be not mindful of my hatred or injustice' (LAB 65.5). ${ }^{77}$

1 John 3:14-15 contrasts murder with love based on the Cain and Abel narrative, with the practical issue being sharing material possessions with a needy brother: 'We know that we have passed from death to life because we love one another. Whoever does not love abides in death. All who hate a brother or sister [by not sharing their possessions] are murderers'.

In these biblical and post-biblical Jewish accounts murder is prevented through love. Is there evidence in 1 Corinthians of Paul pointing to love as the ultimate solution to the murderous antisocial vices that are destroying the church of God in Corinth?

At first blush, the call to love seems to be of limited significance in 1 Corinthians. Whereas in 1 Corinthians 13:1-14:1, the so-called love chapter, the word 'love' occurs no fewer than ten times in fourteen

\footnotetext{
76 This saying is found in the LXX, Samaritan, Syriac, and Vulgate versions, but it is lacking in the MT. The LXX vocabulary for the verb and indirect object in Gen. 4:8 and 1 Sam. 20:11 are different, but this does not disturb the motif of the field as the place for murder and warfare. See Deut. 21:1; 22:25-27; Judg. 9:32,43; 1 Sam. 4:2; 30:11; 2 Sam. $11: 23 ; 14: 6 ; 18: 6 ; 20: 12$; Jer. $6: 25$. Philo makes an allegorical point about the field to which Cain invited Abel: it is the field of 'rivalry and contention' (Det. 1). Jacob calls Leah and Rachel to the plain of revolt and contention (Det. 4). Joseph is found in a plain which symbolises the contention of words (Det. 28). See also Det. 32.
}

77 Tr. D. J. Harrington, OTP 2:377. 
verses, besides these occurrences, 'love' appears only three times in the rest of the letter $(8: 1 ; 16: 14,24)$. Almost every commentator recognises that 1 Corinthians 13 occupies the middle of an A-B-A structure in chapters 12-14 (similar to that found in chapters 8-10), where the first and last of the three chapters (the A elements) deal with the same subject matter (spiritual gifts in chs 12,14) and the middle chapter (B) focuses on a key for dealing with the issue in the proper manner. ${ }^{78}$ Thus, in its immediate literary context, 1 Corinthians 13 extols love as the most perfect way of exercising the gifts of the Spirit.

However, to limit the motif of love in 1 Corinthians to chapters $12-$ 14 is in fact a serious underestimation. 1 Corinthians 13 provides the most important key for dealing with all of the problems that plagued the Corinthians. 1 Clement, a letter also written to the church of God in Corinth, is an early pointer in this direction, when it alludes to 1 Corinthians 13 and applies love to the problem of divisions (found in 1 Cor. 1-4): 'Love knows nothing of schisms, love leads no rebellions, love does everything in harmony' (1 Clem. 49.5). ${ }^{79}$

Michael Gorman has observed that that the positive values of love (not boastful, envious, etc.) are the opposite of how Paul describes Corinthian behaviour across the letter: 'we may consider the characteristics of love and the antisocial vices of the Corinthians side by side' ${ }^{80}$ Love in 1 Corinthians 13 is "a kind of "anti-description" of the Corinthians' ${ }^{81}$ As such, love is the solution to the destructive behaviour of the Corinthians believers which Paul opposes throughout the letter.

If love is 'patient', the Corinthians do not wait for each other when they eat the Lord's Supper (11:20-22,33). If love is not envious, among the Corinthians there is envy and quarrelling ( $3: 3)$. If love is not boastful, the Corinthians are boastful (e.g. 4:7; cf. 1:29-31; 3:21; 5:6). If love is not arrogant, the Corinthians are arrogantly puffed up (see $4: 6 ; 4: 18-19$; $5: 1-2 ; 8: 1 b)$. If love is not rude, the Corinthians are behaving shamefully $(5: 1-2 ; 6: 12-20 ; 7: 36 ; 11: 2-16,20-22)$. If love does not insist on its own way, the Corinthians seek their own advantage $(10: 24,33)$. If love is not irritable, the Corinthians engage in divisions and rivalry. If love is not resentful, the Corinthians take each other to court (6:1-11). If love does

\footnotetext{
78 In chapters 8-10, chapter 9 speaks of Paul's example of waiving rights for the sake of the gospel with a view to eating food sacrificed to idols.

79 Tr. Michael W. Holmes, ed., The Apostolic Fathers: Greek Texts and English Translations ( $3^{\text {rd }}$ edn; Grand Rapids: Baker Academic, 2007)

80 Gorman, Cruciformity, 224.

81 Gorman, Cruciformity, 223. See 224-26 for details.
} 
not rejoice in wrongdoing, the Corinthians wrong each other (6:7-8). If love rejoices in the truth, the Corinthians need to be told to celebrate in truth (5:8). If love bears all things, the Corinthians need to learn from Paul, who willingly endures all kinds of deprivations (9:12). If love believes and hopes all things, the Corinthians need to be reminded of their faith in the hope of resurrection (ch. 15). ${ }^{82}$

In 1 Corinthians 16 Paul closes the letter with five crisp exhortations (vv. 13-14). The fifth represents the key to the Corinthian spiritual immaturity that explains every problem Paul deals with in the letter: 'let all that you do be done in love' (16:14). Significantly, when Paul writes a greeting in his own hand the final thought he leaves with the Corinthians is of his own love for them (v. 24): 'My love be with all of you in Christ Jesus. Amen.' Paul had already highlighted his love for the Corinthians (using cognates of the word $\dot{\alpha} \gamma \alpha \dot{\alpha} \pi \eta$ (love)) in 4:14 ('beloved children'), 10:14 ('my dear friends'), and 15:58 ('my beloved'). Furthermore, his example recalls 1 Corinthians 13, especially verses 13, where Paul states 'If I speak in the tongues of mortals and of angels, but do not have love, I am a noisy gong or a clanging cymbal' and so on.

Far from an emphasis confined to Paul's discussion of spiritual gifts, the motif of love, so beautifully expounded in chapter 13, undergirds all of Paul's moral teaching in this letter. John Chrysostom agrees, arguing that the problems in Corinth arose from the absence of love. In commenting on 16:14 he wrote, "let all be in love:" - since in fact all the things which have been mentioned arose from neglect of it. ${ }^{83}$ Arguably, Paul's emphasis on love as the solution to the destructive behaviours of the Corinthians is in part due to the influence of the murder commandment mediated to him via a long tradition of Jewish moral teaching which regarded love as the opposite of murder.

In 1 Corinthians Paul addresses the problem of potentially destructive antisocial vices in the community by pointing the church of God in Corinth to the way of love as the way not to revile and destroy one

82 Love in chapter 13 also connects to the letter's focus on resurrection and final consummation in chapter 15. The eschatological nature of love is seen in Paul's affirmations that it 'endures' (v. 13) even when most things will be abolished or set aside (vv. 8,10,11), that it 'never falls/fails' (v. 8), and its eschatological implications in vv. 23. Thomas Söding, Das Liebesgebot bei Paulus: Die Mahnung zur Agape im Rahmen der Paulinischen Ethik (Münster: Aschendorff, 1995): 131 states that Paul refers to 'love' here as 'God's eschatological power'.

83 John Chrysostom, Hom 1 Cor. 44:2 (NPNFI 12:264). Cf. Hom. 1 Cor 20:2: 'all these evils were springing from the following root, i.e., not from perfect knowledge, but from their not greatly loving nor sparing their neighbors' $\left(N P N F^{l} 12: 112\right)$. 
another, which is tantamount to murder. In doing so he perpetuates the wisdom of Leviticus 19:11-18 and Jewish tradition that not only regards such vices as murderous, but also promotes love as the answer.

\section{Conclusion}

Despite the fact that Paul does not quote it in the letter, there is good evidence that the murder commandment, in line with its interpretation in Paul's Jewish inheritance, is a fundamental presupposition of Paul's moral teaching in 1 Corinthians. Support for this conclusion can be found in Paul's use of murder as a metaphor and of antisocial vices as synecdoches for the murder commandment, his concern about the moral impurity of such murder, and the close relationship between Paul's call to love and his call to forsake such antisocial vices.

Given Paul's view that believers in Christ are not under the law (1 Cor. 9:21) and that the power of sin is the law (1 Cor. 15:56), how are we to understand his positive appropriation of the murder theme? While answering this question is beyond the scope of this article, the impression that Paul seems to have internalised the murder commandment, and makes reflective and expansive applications of it, supports the view that rather than reading the Law as commandments to be obeyed, as lawcovenant, it remains a critical and formative source for his moral teaching as wisdom for living. ${ }^{84}$

84 On the law as wisdom in Paul's ethics see Rosner, Paul and the Law, ch. 6; Rosner, 'Written for our instruction: The Law as Wisdom in Paul's Ethics', Journal for the Study of Paul's Letters 3.2 (2013): 129-44. For this approach applied to 1 Corinthians in the broadest terms see Rosner, 'Paul and the Law in 1 Corinthians' in Scripture, Texts, and Tracings in 1 Corinthians, ed. Linda L. Belleville and B. J. Oropeza (London: Lexington Books/Fortress Academic, 2019): 99-110. 